\title{
Prevertebral Abscess
}

National Cancer Institute

\section{Source}

National Cancer Institute. Prevertebral Abscess. NCI Thesaurus. Code C128325.

An abscess that develops in the tissues within the prevertebral fascia. 